\title{
An Experimental Study on the Calculation of Optimal Foam Content Ratio for Low-carbon Concrete
}

\author{
Jeyoung Park and Youngshik Park
}

\begin{abstract}
Demand for energy-saving insulator technology development is increasing in South Korea as regulations on energy-efficiency improvement in response to global warming are applied to buildings. To meet this demand, studies on thermal insulation type panels are increasing; however, they merely aim to improve the performance of organic and inorganic insulation materials. In this study, experimental research was performed to find the optimal mix for concrete base in terms of insulation performance using aerated concrete and lightweight aggregates, which have received little attention in insulation research.
\end{abstract}

Keywords - Thermal insulation, lightweight aggregates, aerated concrete, concrete panel, PC panel, sound insulation

\section{INTRODUCTION}

This study is a preliminary property test for a concrete mix for producing precast concrete panels applying a heat-metastructure. Thus, the objective of this study is to determine the optimal foam content ratio in the concrete. Going beyond the existing organic insulation materials, the possibility of commercializing inorganic insulation materials is explored, and a functional product is developed.

\section{A. Domestic and overseas market trends and sizes}

Demand for energy-saving insulator technology development is increasing in South Korea as regulations on energy-efficiency improvement in response to global warming are applied to buildings [1]. Organic insulation materials account for approximately $72 \%$ of the Korean domestic insulating materials market, and among them, EPS and PU-based insulating materials have more than $60 \%$ market share. The demand for organic insulating materials is expected to increase from 460,000 tons in 2014 to 620,000 tons in 2020 [2] [3], but their market share is expected to decrease gradually with the strengthening of fireproof certification [3]. In contrast, the domestic market share of inorganic insulation materials is approximately $15 \%$, much lower than the global average share of $55 \%$. Thus, there is not yet widespread use of inorganic insulation materials in Korea. However, the demand for inorganic insulation materials will increase in the future, and we need to prepare for this.

\section{B. Domestic and overseas technology trends}

TABLE I

PATENT TREND FOR HIGH THERMAL INSULATION PANEL

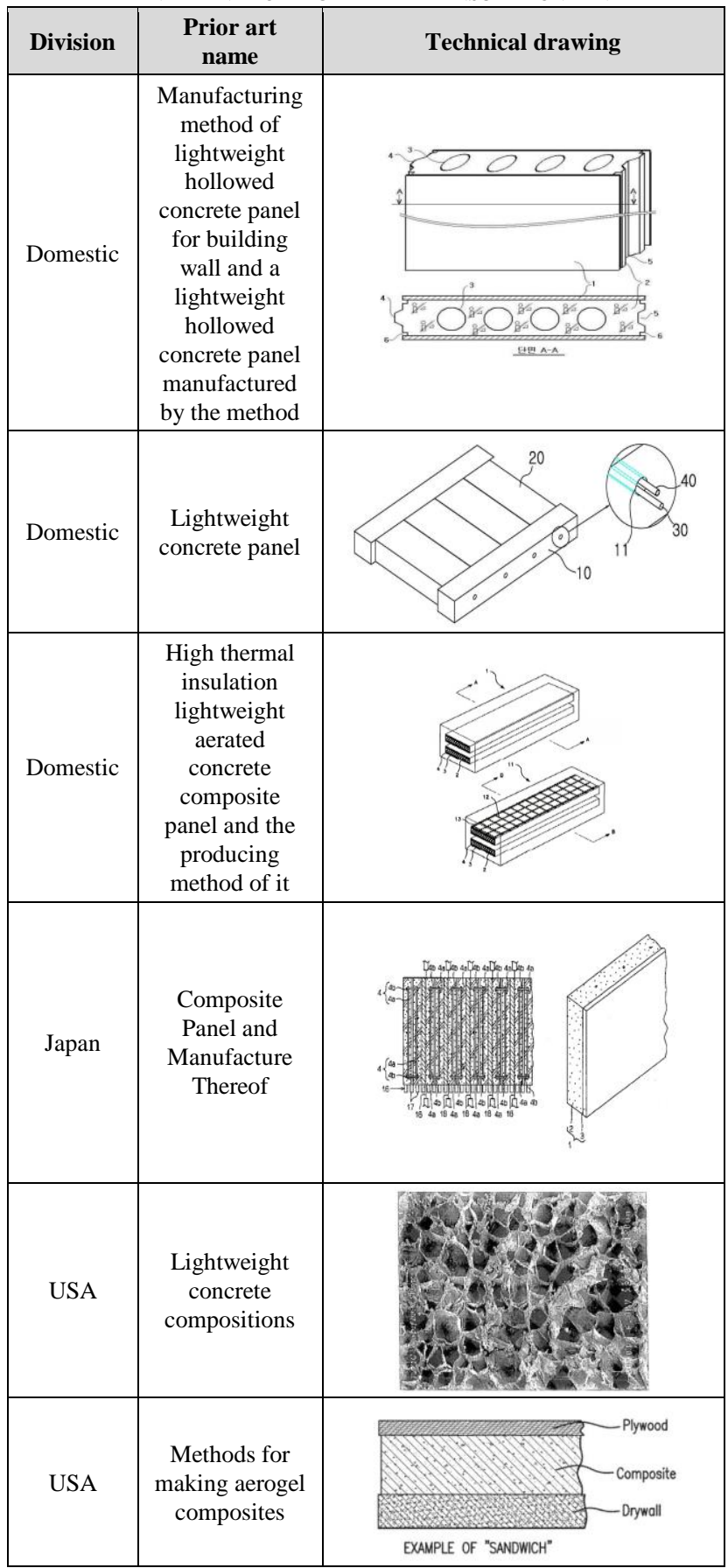


Domestic studies on PC panels have generally focused on evaluating the compressive strength performance and thermal conductivity of PC panels based on lightweight aggregate concrete or aerated concrete [5]-[7]. Furthermore, domestic studies on aerated concrete have mainly focused on evaluating the basic physical properties of concrete to achieve performance improvement and economic efficiency by applying industrial byproducts such as fly ash or blast furnace slag [8]-[9]. In contrast, domestic research on the combination of bubbles and bottom ash lightweight aggregate concrete is very insufficient [10].

Most overseas studies on aerated concrete concern ALC that has undergone high-temperature, high-pressure curing. Similar to domestic studies, they aimed to evaluate the basic physical properties and achieve performance improvement, environmental friendliness, and economic efficiency of aerated concrete by replacing industrial byproducts. A few overseas researchers have conducted studies on the fusion of bubbles and mortar [11], but there have been no studies aiming to improve thermal insulation at the concrete level.

Many studies have been conducted to improve the high unit volume weight and low thermal insulation of PC panels domestically and abroad. However, their main focus is on improving physical performance and securing economic efficiency, and the PC panels developed in these studies achieved only slight improvement in thermal insulation. Domestic and overseas patents related to lightweight aerated concrete panel, lightweight concrete panel, and foamed styrene panel mostly concern thermal and sound insulation and feature limited compressive strength and fire resistance. To improve fire resistance and insulation performance, patented technology considering a combination of components different from prior patents or a new manufacturing method is required. Therefore, continued research is necessary not only on the composition and manufacturing methods related to lightweight aerated concrete panel, lightweight concrete panel, and foamed styrene panel technologies, but also on the detailed structures using these technologies. In the present study, we attempted an experimental approach to achieve this.

\section{EXPERIMENTAL OVERVIEW}

The physical properties and chemical composition of the ordinary Portland cement (OPC), ground granulated blast-furnace slag (GGBS), and fly ash (FA) used in the mix are summarized below. The density and specific surface area of the OPC are $3.15 \mathrm{~g} / \mathrm{cm} 3$ and $3,260 \mathrm{~cm} 2 / \mathrm{g}$, respectively, and the main chemical components are $62.4 \% \mathrm{CaO}$ and $21.7 \% \mathrm{SiO} 2$, which account for more than $80 \%$ of the total chemical components.

The density and specific surface area of GGBS are 2.94 $\mathrm{g} / \mathrm{cm} 3$ and $4,355 \mathrm{~cm} 2 / \mathrm{g}$, respectively, and the major chemical components are $43.9 \% \mathrm{CaO}$ and $33.5 \% \mathrm{SiO} 2$, which account for more than $70 \%$ of the total chemical components. The density and specific surface area of FA are $2.20 \mathrm{~g} / \mathrm{cm} 3$ and $4,170 \mathrm{~cm} 2 / \mathrm{g}$, respectively

\section{A. Experimental Materials}

The physical properties of major binders are listed in Table II.

TABLE II

PHYSICAL PROPERTIES AND CHEMICAL COMPOSITION OF GGBS AND FA

\begin{tabular}{|c|c|c|c|c|c|c|c|}
\hline \multicolumn{8}{|c|}{ Physical properties } \\
\hline \multicolumn{2}{|c|}{ Material } & \multicolumn{2}{|c|}{ Density (g/cm3) } & \multicolumn{2}{|c|}{$\begin{array}{c}\text { Specific surface } \\
\text { area }(\mathrm{cm} 2 / \mathrm{g})\end{array}$} & \multicolumn{2}{|c|}{$\begin{array}{c}\text { Water conten } \\
(\%)\end{array}$} \\
\hline \multicolumn{2}{|c|}{ GGBS } & \multicolumn{2}{|c|}{2.94} & \multicolumn{2}{|c|}{4,355} & \multicolumn{2}{|c|}{0.23} \\
\hline \multicolumn{2}{|c|}{ FA } & \multicolumn{2}{|c|}{2.20} & \multicolumn{2}{|c|}{4,170} & \multicolumn{2}{|c|}{0.1} \\
\hline \multicolumn{8}{|c|}{ Chemical composition (\%) } \\
\hline Material & $\mathrm{SiO} 2$ & Al2O3 & $\mathrm{Fe} 203$ & $\mathrm{CaO}$ & MgO & SO3 & LOI \\
\hline GGBS & 33.5 & 15.2 & 0.5 & 43.9 & 2.6 & 2.5 & 3.9 \\
\hline FA & 57.7 & 21.1 & 6.4 & 4.3 & 1.8 & 0.5 & 3.9 \\
\hline
\end{tabular}

The physical properties of the bottom ash lightweight aggregates used in this study are outlined in Table III. To satisfy the particle size distribution of KS F 2527 for the fine aggregates, materials with particle sizes smaller than $2 \mathrm{~mm}$ and materials with particle sizes of $2-4 \mathrm{~mm}$ were mixed at a weight ratio of 7:3. The maximum sizes of the bottom ash lightweight fine aggregates and coarse aggregates are $4 \mathrm{~mm}$ and $13 \mathrm{~mm}$, respectively, and the fineness moduli are 2.74 and 6.55, respectively. The absorptivity values of fine aggregates and coarse aggregates are $11.1 \%$ and $15.3 \%$, respectively, and the dry air density values are $1.79 \mathrm{~g} / \mathrm{cm} 3$ and $1.18 \mathrm{~g} / \mathrm{cm} 3$, respectively. The surface and interior of the bottom ash lightweight aggregates have many air voids, as shown in Fig. 1. Their density ranged from 0.92 to $1.52 \mathrm{~g} / \mathrm{cm} 3$, which corresponds to approximately $42-65 \%$ of that of general aggregates.

TABLE III

PHYSICAL PROPERTIES OF BOTTOM ASH LIGHTWEIGHT AGGREGATES

\begin{tabular}{|c|c|c|c|c|}
\hline $\begin{array}{c}\text { Aggregate } \\
\text { type }\end{array}$ & $\begin{array}{c}\text { Maximum } \\
\text { size }(\mathbf{m m})\end{array}$ & $\begin{array}{c}\text { Density } \\
\left(\mathbf{g} / \mathrm{cm}^{3}\right)\end{array}$ & $\begin{array}{c}\text { Absorptivity } \\
(\mathbf{\%})\end{array}$ & $\begin{array}{c}\text { Fineness } \\
\text { modulus }\end{array}$ \\
\hline $\begin{array}{c}\text { Fine } \\
\text { aggregates }\end{array}$ & 4 & 1.79 & 11.1 & 2.74 \\
\hline $\begin{array}{c}\text { Coarse } \\
\text { aggregates }\end{array}$ & 13 & 1.18 & 15.3 & 6.55 \\
\hline
\end{tabular}

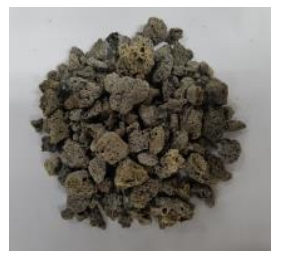

(a) Appearance

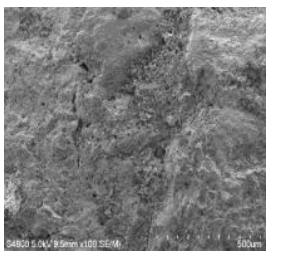

(b) Sur. SEM $(\times 750)$

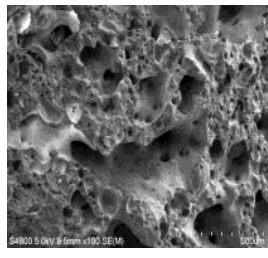

(c) Int. SEM $(\times 750)$
Fig. 1 Appearance and SEM images of bottom ash lightweight aggregates

For the foaming agent, a dark brown liquid animal foam agent with a density of $1.06 \mathrm{~g} / \mathrm{cm} 3$ was used. 
TABLE IV

PHYSICAL PROPERTIES AND CHEMICAL COMPOSITION OF OPC

\begin{tabular}{|c|c|c|c|c|c|c|}
\hline \multicolumn{7}{|c|}{ Physical properties } \\
\hline \multirow{7}{*}{$\begin{array}{c}\text { Density } \\
\left(\mathbf{g} / \mathbf{c m}^{3}\right)\end{array}$} & $\begin{array}{c}\text { Specific } \\
\text { surface } \\
\text { area } \\
\left(\mathbf{c m}^{2} / \mathbf{g}\right)\end{array}$ & $\begin{array}{c}\text { Stability } \\
(\%)\end{array}$ & \multicolumn{3}{|c|}{ Setting time (min) } \\
\cline { 4 - 7 } & & & Initial set & \multicolumn{2}{|c|}{ Final set } \\
\hline 3.15 & 3,260 & 0.05 & 230 & \multicolumn{2}{|c|}{345} \\
\hline \multicolumn{7}{|c|}{ Chemical composition (\%) } \\
\hline SiO2 & Al203 & Fe203 & CaO & MgO & SO3 & LOI \\
\hline 21.7 & 5.3 & 3.1 & 62.4 & 1.6 & 1.7 & 0.8 \\
\hline
\end{tabular}

\section{B. Mixing plan}

The mixing details of the bottom ash lightweight aggregate concrete are described here. The main variable of groups 1 to 3 is foam content ratio $(0 \%, 10 \%$, and $25 \%$, respectively). The unit binder quantity was changed to $450 \mathrm{~kg} / \mathrm{m} 3$. The curing conditions of the mix were as follows: continuous curing at $20{ }^{\circ} \mathrm{C}$ after mixing, curing at $40{ }^{\circ} \mathrm{C}$ and $60{ }^{\circ} \mathrm{C}$ for $10 \mathrm{~h}$, and constant temperature and humidity $\left(20{ }^{\circ} \mathrm{C}\right.$ and $60 \%$, respectively).

The basic common conditions of the mix are the binder ratio (OPC 30\%, GGBS 50\%, and FB 20\%) and 100\% bottom ash lightweight aggregates (coarse aggregates and fine aggregates).

The main fabrication process of the concrete mix is shown in Fig. 2. To produce the concrete mix, bottom ash aggregates and binder were mixed in dry condition for approximately $2 \mathrm{~min}$. Then wet mixing was performed by adding water, and then a water-reducing agent was added. The foam was added last by generating compressed air using a foaming agent diluted in water at a concentration of $2.5 \%$.

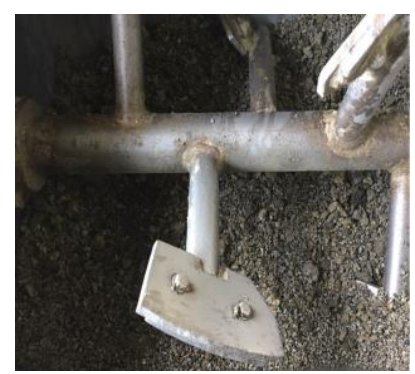

(a) Adding aggregates

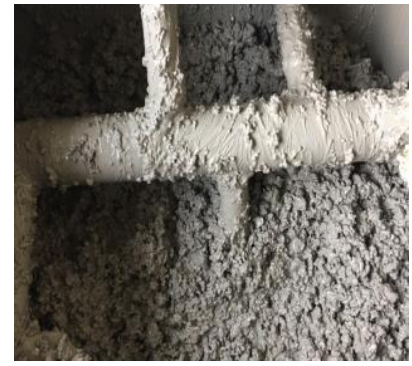

(c) Adding mixing water

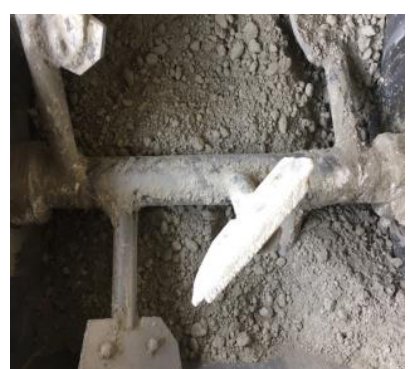

(b) Dry mixing

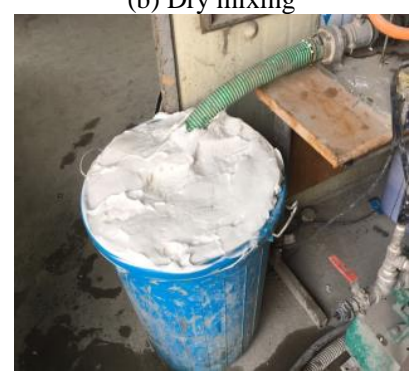

(d) Generating foam

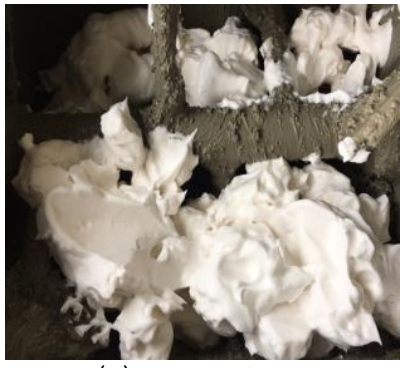

(e) Adding foam

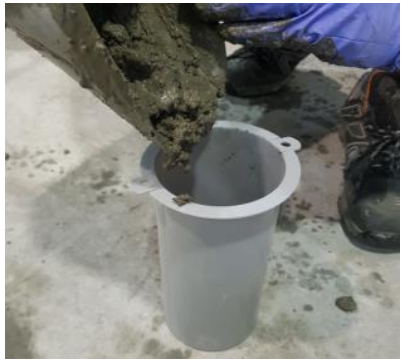

(g) Fabrication of compressive strength specimen

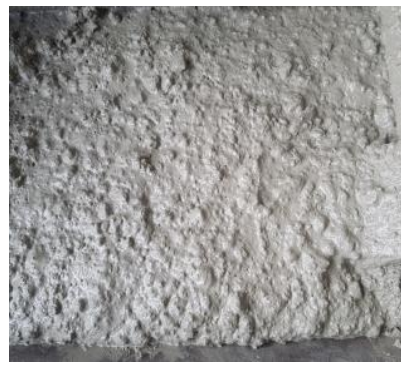

(f) Mix completed

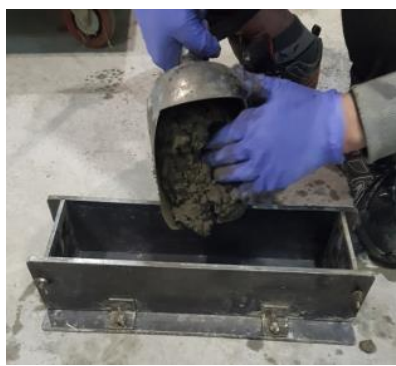

(h) Fabrication of specimen for coefficient of rupture
Fig. 2 Mix sequence of bottom ash lightweight aggregate concrete

\section{C.Details of experimental mixes}

The experimental mixes are outlined in Table V.

TABLE V

MIX DETAILS OF SPECIMENS

\begin{tabular}{|c|c|c|c|c|c|}
\hline \multirow{2}{*}{ Specimens } & \multirow{2}{*}{$\begin{array}{l}W / B \\
(\%)\end{array}$} & \multirow{2}{*}{$\begin{array}{c}\text { Foam } \\
(\%)\end{array}$} & \multicolumn{3}{|c|}{$\begin{array}{c}\text { Composition ratio of binder } \\
\text { (wt \%) }\end{array}$} \\
\hline & & & OPC & GGBS & FA \\
\hline $25-\mathrm{F} 0 \%$ & \multirow{3}{*}{25} & 0 & \multirow{3}{*}{30} & \multirow{3}{*}{50} & \multirow{3}{*}{20} \\
\hline $25-\mathrm{F} 10 \%$ & & 10 & & & \\
\hline $25-\mathrm{F} 25 \%$ & & 25 & & & \\
\hline $30-\mathrm{F} 0 \%$ & \multirow{3}{*}{30} & 0 & \multirow{3}{*}{30} & \multirow{3}{*}{50} & \multirow{3}{*}{20} \\
\hline $30-\mathrm{F} 10 \%$ & & 10 & & & \\
\hline $30-\mathrm{F} 25 \%$ & & 25 & & & \\
\hline
\end{tabular}

\section{RESULTS}

\section{A. Uncured concrete}

The mix could not be poured due to 0-mm slump. However, every other mix satisfied the target slump, and the slurry density exceeded the predicted value of ASTM C 567. Sedimentation due to a difference in specific gravity between the slurry and aggregates was not observed. 
TABLE VI

EXPERIMENT RESULTS BY SPECIMEN

\begin{tabular}{|c|c|c|c|c|c|}
\hline \multirow{2}{*}{$\begin{array}{l}\text { Specime } \\
\text { n name }\end{array}$} & \multirow{2}{*}{$\begin{array}{c}\text { Foam } \\
\text { content } \\
\text { ratio } \\
(\%)\end{array}$} & \multirow{2}{*}{$\begin{array}{c}\text { Actual } \\
\text { foam } \\
\text { ratio } \\
(\%)\end{array}$} & $\begin{array}{l}\text { Slurry } \\
\text { density } \\
\left(\mathrm{kg} / \mathrm{m}^{3}\right)\end{array}$ & \multirow{2}{*}{$\underset{\substack{\text { Slum } \\
(\mathbf{m m})}}{\text { Sh }}$} & \multirow{2}{*}{$\begin{array}{c}\text { Settl } \\
\text { emen } \\
\mathbf{t} \\
\text { dept } \\
\mathbf{h} \\
(\mathrm{mm})\end{array}$} \\
\hline & & & $\begin{array}{c}\text { Measur } \\
\text { ement }\end{array}$ & & \\
\hline $25-\mathrm{F} 0 \%$ & 0 & 0 & \multicolumn{3}{|c|}{$\begin{array}{l}\text { Filling is impossible due to } \\
0 \mathrm{~mm} \text { slump }\end{array}$} \\
\hline $25-\mathrm{F} 10 \%$ & 10 & 12.5 & 1,582 & 210 & 0 \\
\hline $25-\mathrm{F} 25 \%$ & 25 & 20 & 1,366 & 205 & 0 \\
\hline $30-\mathrm{F} 0 \%$ & 0 & 0 & 1,620 & 50 & 0 \\
\hline $30-\mathrm{F} 10 \%$ & 10 & 7.5 & 1,541 & 150 & 0 \\
\hline $30-\mathrm{F} 25 \%$ & 25 & 17.5 & 1,320 & 165 & 0 \\
\hline
\end{tabular}

\section{B. Cured concrete}

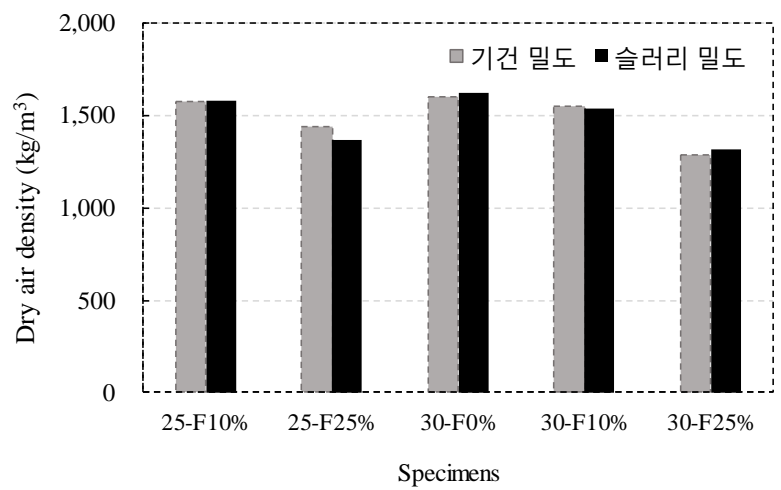

Fig. 3 Comparison of dry air density and slurry density

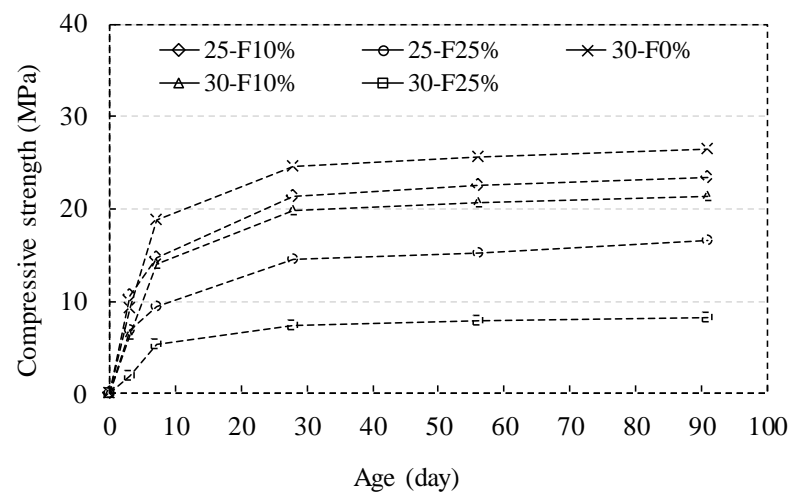

Fig. 4 Compressive strength by age for curing at room temperature

Every mix except for 30-F25\% satisfied the target strength. The dry air density and compressive strength decreased with increasing foam content ratio.

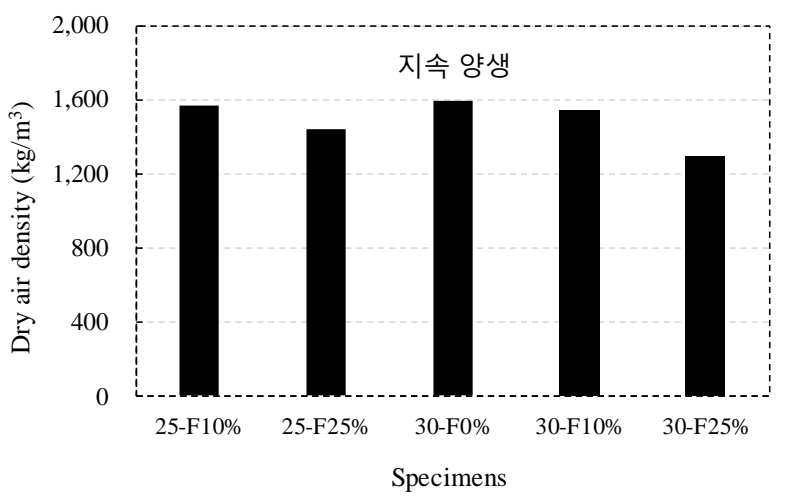

Fig. 5 Dry air density for curing at $60^{\circ} \mathrm{C}$

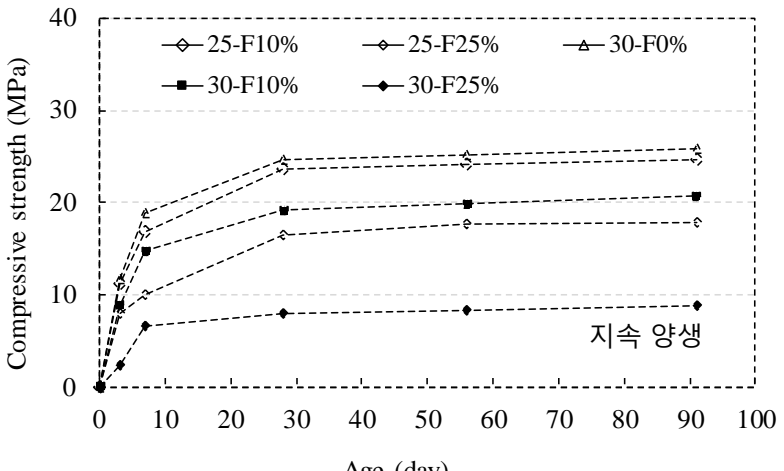

Fig. 6 Compressive strength and dry air density by age at $60^{\circ} \mathrm{C}$

TABLE VII

BENDING STRENGTH, SPLITTING TENSILE STRENGTH, AND DRYING SHRINKAGE

\begin{tabular}{|c|c|c|}
\hline Specimen name & $\boldsymbol{f}_{\text {sp }} / \widehat{ }_{\mathbf{f k}}$ & $\boldsymbol{f}_{\mathbf{r}} /{ }_{\mathbf{f}_{\text {ck }}}$ \\
\hline $25-\mathrm{F} 10 \%$ & 0.335 & 0.574 \\
\hline $25-\mathrm{F} 25 \%$ & 0.303 & 0.548 \\
\hline $30-\mathrm{F} 0 \%$ & 0.350 & 0.667 \\
\hline $30-\mathrm{F} 10 \%$ & 0.305 & 0.555 \\
\hline $30-\mathrm{F} 25 \%$ & 0.288 & 0.500 \\
\hline
\end{tabular}

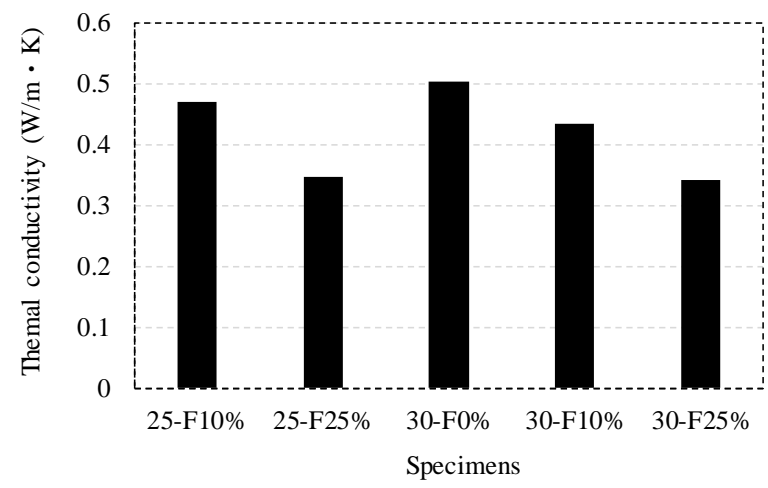

Fig. 7 Thermal conductivity 
TABLE VIII

THERMAL CONDUCTIVITY AND HEAT TRANSMISSION RATE

\begin{tabular}{|c|c|c|}
\hline Specimen name & $\begin{array}{c}\text { Thermal } \\
\text { conductivity } \\
(\mathbf{W} / \mathbf{m} \cdot \mathbf{K})\end{array}$ & $\begin{array}{c}\text { Converted heat } \\
\text { transmission rate } \\
(\mathbf{W} / \mathbf{m} \mathbf{2} \cdot \mathbf{K})\end{array}$ \\
\hline $25-\mathrm{F} 10 \%$ & 0.471 & 0.288 \\
\hline $25-\mathrm{F} 25 \%$ & 0.347 & 0.278 \\
\hline $30-\mathrm{F} 00 \%$ & 0.505 & 0.290 \\
\hline $30-\mathrm{F} 10 \%$ & 0.434 & 0.286 \\
\hline $30-\mathrm{F} 25 \%$ & 0.342 & 0.278 \\
\hline
\end{tabular}

The thermal conductivity and heat transmission rate decreased with increasing foam content ratio.

\section{CONCLUSIONS}

The thermal conductivity of the specimens ranged from 0.342 to $0.505 \mathrm{~W} / \mathrm{m} \cdot \mathrm{K}$, approximately $83 \%$ compared to that of normal-weight concrete, $2.4 \mathrm{~W} / \mathrm{m} \cdot \mathrm{K}$. However, thermal conductivity must be lowered further, because it is still $40 \%$ higher than the target heat transmission rate, $0.2 \mathrm{~W} / \mathrm{m} 2 \cdot \mathrm{K}$.

(1) In every mix, the measured slurry density was higher than the predicted slurry density.

(2) The optimal mix conditions to satisfy the target compressive strength of $10 \mathrm{MPa}$, the target dry air density of $1,300-1,600 \mathrm{~kg} / \mathrm{m} 3$ and the target slump of $150 \mathrm{~mm}$ are as follows: $25 \%$ foam content ratio, $25 \% \mathrm{~W} / \mathrm{B}, 205 \mathrm{~mm}$ slump, 91 days of age, 17.9MPa compressive strength, and 17.9MPa dry air density. The curing condition is continuous curing at a high temperature $\left(60^{\circ} \mathrm{C}\right)$.

(3) The converted heat transmission rate was 0.274 $\mathrm{W} / \mathrm{m} 2 \cdot \mathrm{K}$ (including heat-meta and insulating materials), which did not satisfy the target condition of $0.2 \mathrm{~W} / \mathrm{m} 2 \cdot \mathrm{K}$. The results of this experiment will be used as basic data for determining the optimal mix condition to meet this target.

\section{ACKNOWLEDGMENT}

This research was supported by a grant (19CTAP-C151900-01) from the Technology Advancement Research Program funded by the Ministry of Land, Infrastructure and Transport of Korean government and the Korea Agency for Infrastructure Technology Advancement.

\section{REFERENCES}

[1] Kim, D. W., Chung, K. S., Kim, Y. I., \& Kim, S. M. (2013). A comparative study on heating energy consumption for apartment based on the annually strengthened criteria of insulation. Journal of Energy Engineering, 22(2), 83-89. https://doi.org/10.5855/ENERGY.2013.22.2.083

[2] Park, J. M., Kim, D. H., \& Suh, D. J. (2012). Recent research trends for green building thermal insulation materials. Clean Technology, 18(1), 14-21.

https://doi.org/10.7464/ksct.2012.18.1.014

[3] Song, H. (2015). Present condition and countermeasure of fire retardant and combustible insulation materials. Review of Architecture and Building Science, 59(5), 34-37.
[4] Seo, D. H., Kim, W. H., Kim, J. H., \& Lee, Y. J. (2017). An experimental study of sprinkler system for sandwich panel wall protection. Fire Science and Engineering, 31(5), 37-43. https://doi.org/10.7731/KIFSE.2017.31.5.037

[5] Cho, S. K., Kwark, J. W., Lee, J. M., \& Moon, D. J. (2006). Punching shear behavior of high-strength lightweight concrete slab under concentrated load. Journal of the Korean Society of Civil Engineers, 26(1A), 219-228.

[6] Chung, S. Y., Han, T. S., Yun, T. S., \& Youm, K. S. (2013). Evaluation of the anisotropy of the void distribution and the stiffness of lightweight aggregates using CT imaging. Construction and Building Materials, 48, 998-1008. https://doi.org/10.1016/j.conbuildmat.2013.07.082

[7] Kim, H. S., Lee, S. H., Sun, J. S., \& Kim, J. M. (2016). A physical properties of lightweight foamed concrete according to lightweight aggregate types and foaming agent types. Journal of the Korea Concrete Institute, 28(4), 435-444.

https://doi.org/10.4334/JKCI.2016.28.4.435

[8] Lee, S. S., \& Song, H. Y. (2007). An experimental study on the durability and mechanical properties of high performance concrete using blast-furnace slag powder. Journal of the Architectural Institute of Korea Structure \& Construction, 23(11), 119-126.

[9] Lee, M. H, Moon, J. W. (2007). A study on the concrete special quality by the mixing method with fly ash. Journal of the Architectural Institute of Korea Structure \& Construction, 23(9), 175-184.

[10] Kim, S. C., \& Ahn, S. K. (2009). Mix design and characteristics of compressive strengths for foam concrete associated with the application of bottom ash. Journal of the Korea Concrete Institute, 21(3), 283-290. https://doi.org/10.4334/JKCI.2009.21.3.283

[11] Wang, Q. X., Shi, Y. X., Shi, J. B., Zhang, Y. G., \& Liu, W. (2015, November). An experimental study on thermal conductivity of ceramsite cellular concrete. In 2015 International Conference on Structural, Mechanical and Material Engineering. Atlantis Press. https://doi.org/10.2991/icsmme-15.2015.16

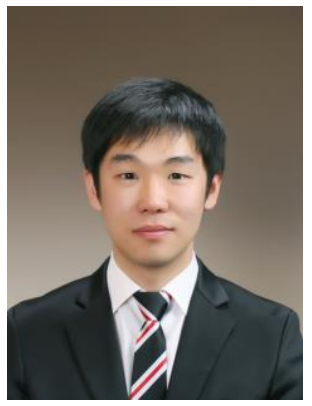

Jeyoung Park, full-time researcher, received a master's degree with "A Study on Behavior of PPSC Beam Using GFRP Rebar" at the Concrete Structure Laboratory of Hanyang University in South Korea. He worked at POSCO from 2013 and is now working as researcher in IS Dongseo Technology Research Center.

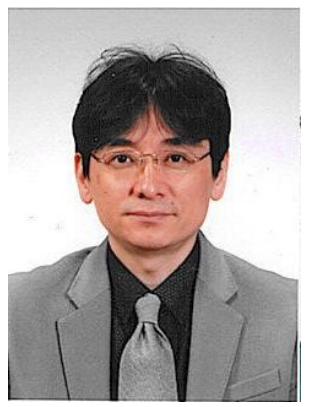

Youngshik Park, senior researcher, received master's and Ph.D. degrees with studies on concrete durability from Yeongnam University in South Korea. He worked as a professor at Kundong University from 1997 to 2010 and is now working as Director of IS Dongseo Technology Research Center. 